\title{
The influence of the clothing sales assistant on the female consumer's purchasing decision: an exploratory investigation
}

\author{
Daleen van der Merwe, Marlize Stoltz \& Sonica Jacobs
}

\begin{abstract}
Opsomming
Die doelwitte van hierdie studie was om vroulike verbruikers se persepsies en emosies aangaande die klere-verkoopsassistent in die klerekleinhandel te bepaal. Die invloed van die bystand en diensverskaffing van die klere-verkoopsassistent op die verbruiker se aankoopbesluit is ook bepaal. 'n Kwalitatiewe navorsingsstrategie is gevolg. Semi-gestruktureerde onderhoude is gebruik vir data-insameling om onderhoude met respondente in 'n bekende Suid-Afrikaanse klerekettingwinkel te voer. Die meerderheid van die respondente het dieselfde verwagtinge gehad, wat eienskappe ingesluit het waarna die verkoopsassistent behoort te streef en te vermy. Die respondente se verwagtinge van die kenmerke van die verkoopsassistent, asook hulle positiewe of negatiewe ingesteldheid teenoor die klere-verkoopsassistent, het hulle persepsies beïnvloed. Hulle aankoopbesluit is negatief beïnvloed deur ' $n$ verskeidenheid emosies wat uitgelok is deur die klere-verkoopsassistent. Die verskillende tipes aankoopbesluite wat voortvloei uit die diensverskaffing en bystand van die klere-verkoopsassistent sal die kleinhandelaar se verkope laat toeneem, afneem, of geensins beïnvloed nie. Die resultate van hierdie studie is van belang vir die klerekleinhandel, omdat verbruikers se aankoopgedrag die wins van klerewinkels sal beïnvloed.
\end{abstract}

\section{- Ms D van der Merwe*}

Department of Consumer Sciences North-West University, Potchefstroom

\section{- Ms M Stoltz}

Department of Consumer Sciences

North-West University, Potchefstroom

\section{- Ms Sonica Jacobs}

Department of Consumer Sciences

North-West University, Potchefstroom

\section{Acknowledgements}

The authors wish to thank the Efficient Consumer Response (ECR) in South Africa for financial assistance. The technical support of Dr Marietjie Venter, Ms Ment Larney, and Prof. Annette van Aardt are also acknowledged with gratitude.

\section{INTRODUCTION}

Despite the fact that South Africa's clothing industry is large and capital and people intensive (Du Preez \& Visser, 2003), not much is known about the clothing shopping behaviour of consumers in the country (Du Preez, 2003). One important factor that contributes to this shopping behaviour is the interaction of the consumer with the staff in the clothing store (Terblanche \& Boshoff, 2003). For instance, the sales assistant plays a critical role in establishing the consumerretailer relationship in a retail store (Sharma, 2001), as the consumer forms a perception of the sales assistant in the early stages of their interaction (Ambady et al, 2006).

Should the right relationship between the sales assistant and the consumer be established in the beginning, the assistant will recognise what the consumer's expectations are and understand more about satisfying his or her needs (Parmentier, 2005). In addition, the consumer's satisfaction with the clothing sales assistant's service evokes particular emotions in the consumer (Menon \& Dubé, 2000). These feelings or emotions that a shopping experience induces in a consumer while in contact with a sales assistant will determine their enjoyment of the shopping experience and, in some instances, whether purchasing will take place (Jones, 1999). Hence, it is necessary to explore consumers' emotions as influenced by the clothing sales assistant because this information will allow clothing sales assistants to improve their selling approach, eliciting favourable emotions in the consumer, in order to promote purchasing and consumer satisfaction.

Thus, the clothing sales assistant, in determining the relationship that is established between the clothing consumer and the retailer, will determine the sales of the store. Consumer research, such as the present study, could therefore play a valuable role in aligning these parties for the future of clothing retail in South Africa. The better the relationship formed between them, the more satisfaction will be experienced on both sides.

Scientific research on clothing stores examining sales assistants' service provision is essential for an understanding of the consumer's purchasing behaviour in relation to the assistance and service provision of the sales assistant. Many studies focus on sales assistants in general retail (Sharma \& Stafford, 2000; Arnold et al, 2005), without specifically mentioning the role of the clothing sales assistant. De Klerk et al (1998) studied the appearance of the clothing sales 
assistant as an influence on the decision-making process of female consumers in South Africa, but the service provided by the assistant was not investigated. This emphasises the lack of research regarding the role of the sales assistant specifically in clothing stores and in a South African context, which prompted the present study.

\section{RESEARCH OBJECTIVES}

The primary objective of this study was to narrow the gap in knowledge of the influence the clothing sales assistant has on the consumer's purchasing decision in a South African context, through an exploratory investigation. The secondary objectives were firstly to determine consumers' perceptions of the clothing sales assistant regarding their service provision; secondly, to examine the effect that the clothing sales assistant has on the consumer's emotions; and lastly, to determine the influence that the clothing sales assistant's service has on consumers' purchasing decision.

\section{CONCEPTUAL BACKGROUND}

\section{Research framework}

Figure 1 presents a research framework of the different concepts of this study according to the research objectives and the literature review following this framework. The sales assistant in a clothing store interacts with the consumer entering the store, thereby establishing a relationship with the consumer. The consumer has particular perceptions of the clothing sales assistant. These perceptions are created through the manner in which the sales assistant approaches the consumer, their behaviour, characteristics, and appearance, as well as existing expectations prior to the interaction. All the above-mentioned have a direct impact on the consumer's emotions, which may influence the consumer's purchasing decision. The following sections present a literature review as indicated in the framework.

The female consumer in clothing retail

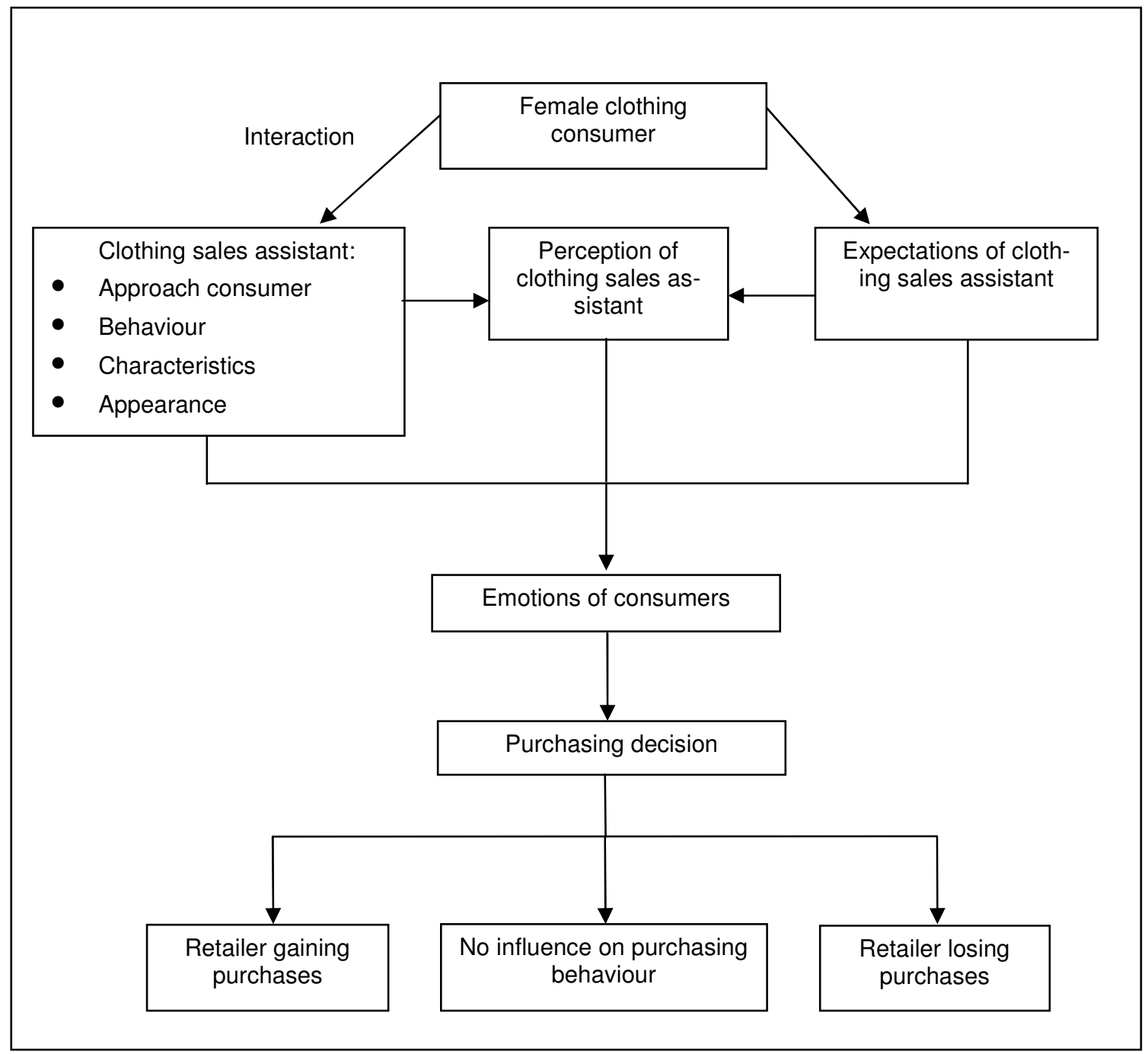

FIGURE 1: CONCEPTUAL FRAMEWORK OF THE INFLUENCE OF THE SALES ASSISTANT ON CONSUMERS' PURCHASING BEHAVIOUR 
As shown in Figure 1, the female clothing consumer is the first concept of this study. Michon et al (2008) in their study find that malls focus increasingly on clothing, emphasising female clothing. Male and female consumers differ particularly in that males tend to make a purchase more quickly, while females require more time to make a decision (Heebner, 2006). As a result, women are seen by the retailers as their best clients. This applies particularly to clothing retail, where the female consumer has an interest in fashion, and thus spends a substantial amount of money and energy on clothing shopping (Kawabata \& Rabolt, 1999). Owing to their unique clothing shopping behaviour and importance to clothing retail, this study focused on the female consumer.

\section{The sales assistant in clothing retail}

The clothing sales assistant is the second important concept of this study (Figure 1). According to Laschinger (2004), South Africa's clothing retailers have changed their image more than expected over the past ten years to fit into the changing South African market. For this reason, clothing retailers, such as Edgars, Foschini, Truworths, and Woolworths, have recreated their images to fit into this market. Highly personalised service provision has a positive impact on the consumer's perception of store image $(\mathrm{Hu} \&$ Jasper, 2006). Furthermore, the sales assistant's characteristics, such as knowledge and personality, together with store location and merchandise suitability, will also determine store image, which in turn will affect the consumer's choice of store (Solomon \& Rabolt, 2004:446).

Blem (2007:10) considers sales assistants from a South African perspective, confirming that they represent an important asset of the store by portraying the store image to the consumer. That their service has not yet been recognised by many organisations is also noted (Blem, 2007:10). However, the current era of competition between retailers for the consumer's support necessitates the adjustment of the retail service for consumers, wherein retail salespeople play a critical role (Sharma, 2001). Thus, a study focusing on the clothing sales assistant is appropriate in the South African context. Because of competition between retailers it is necessary to adjust service quality to the consumer, and therefore salespeople play a critical role in the retail environment (Sharma, 2001:125).

\section{The interaction between the female consumer and sales assistant in clothing retail}

The interaction between the consumer and sales assistant through casual conversation or relationships in general retail is regarded by some consumers as an important form of social interaction ( $\mathrm{Hu} \&$ Jasper, 2006). The clothing sales assistant also has the important function of establishing a long-term relationship with the consumer. Figure 1 indicates that the interaction between the female clothing consumer and the clothing sales assistant is the trigger for establishing the consumer's perceptions regarding the sales assistant, and ultimately determining whether sales will take place.
Four factors regarding the clothing sales assistant's influence on the perception of the consumer have been identified in the literature, namely the manner in which the sales assistant approaches the consumer (Ambady et al, 2006), the sales assistant's behaviour (Sharma, 2001), the characteristics that the sales assistant portrays (Clopton et al, 2001), and the clothing sales assistant's appearance (Regan \& Llamas, 2002; Figure 1). These factors are discussed later in more detail.

The female consumer's interaction with the clothing sales assistant influences whether she will accept advice from the sales assistant and influences her instore behaviour (De Klerk et al, 1998), purchase satisfaction (Menon \& Dubé, 2000), repeat purchasing (De Klerk et al, 1998) and the sales (Reynolds \& Arnold, 2000 ) of a clothing retail store. The quality of the interaction between a sales assistant and consumer is determined by the sales assistant's ability to interpret her needs (Hu \& Jasper, 2006). Their assistance and advice is more significant when purchasing clothes than other goods (Stanforth \& Lennon, 1997), as they can offer knowledge about the merchandise to help the consumer's choice (Solomon \& Rabolt, 2004:449) and because clothing shopping is a more deliberate, focussed and high involvement type of shopping than grocery shopping (Lindquist \& Kaufman-Scarborough, 2004).

Should a consumer experience difficulty in decisionmaking when shopping, it is the sales assistant's responsibility to assist the consumer (Lee \& Dubinsky, 2003) during their interaction in the store. This is because they are normally the first point of contact when a consumer has a problem (Clopton et al, 2001).

\section{Consumers' expectations of a clothing sales assistant}

As indicated in Figure 1, the female clothing consumer has certain expectations of the clothing sale assistant in their interaction. Reynolds and Beatty (1999) confirmed this, stating that the consumer expresses different expectations when in interaction with different persons, such as in the case of the clothing sales assistant. Sales assistants should not strive to only meet consumers' expectations by merely offering product information, but rather to exceed expectations by creating interesting and fun social interactions, rendering the shopping experience enjoyable ( $\mathrm{Hu}$ \& Jasper, 2006).

The consumer expects the sales assistant to be available should he or she have any difficulties during or after a shopping encounter (Sharma \& Stafford, 2000; Sharma, 2001; Low \& Freeman, 2007). The availability of the sales assistant should be equivalent to consumers' expectations, to generate a satisfactory shopping venture for the consumer (Jones, 1999).

Consumers also expect the clothing sales assistant to allow browsing (Jones, 1999), be knowledgeable (Jones 1999; Clopton et al, 2001), and offer fashion advice (Low \& Freeman, 2007). Consumers' expecta- 
tions of the sales assistant can be linked to their perceptions, as expectations are what the consumer thinks is supposed to happen in the store and what they want from their shopping experience (Stanforth \& Lennon, 1997). Thus, their perceptions are likely to be influenced by their original expectations when interacting with the sales assistant. The present study determined whether the South African consumers who participated in the study expressed similar expectations regarding the sales assistant.

\section{Consumers' perceptions of the clothing sales assistant}

It has already been mentioned that female clothing consumers form a perception of the clothing sales assistant based on their expectations of the assistant, as well as the way in which the assistant approaches them, the assistant's behaviour, characteristics, and appearance (Figure 1). Ambady et al (2006) indicate that the success of a sale relies on the consumer's perception of the sales assistant.

Firstly, the consumer forms a perception of the sales assistant during the early stages of interaction based on the way the sales assistant approaches the consumer, even before communication between them (Ambady et al, 2006; Figure 1). An over-ambitious sales assistant can create an unsatisfactory experience for the consumer (Arnold et al, 2005). The same is true for an assistant who 'oversells', by offering unsolicited advice (Schmidt, 2007). It is therefore imperative for the sales assistant not to overwhelm the consumer while they are purchasing merchandise, and that unnecessary sales assistants are not on the sales floor.

Secondly, sales assistants' behaviour may further influence the perception the consumer has of them (Sharma, 2001; Figure 1). For instance, some salespeople are perceived negatively because they do not put the consumer first (Bristow et al, 2006:242).

Thirdly, the characteristics that the sales assistant portrays determine the perception the consumer has of the sales assistant (Clopton et al, 2001; Figure 1). Clothing sales assistants' characteristics that are associated with their competence are age, appearance, performance (Solomon, 2004:348), product knowledge (Clopton et al, 2001), knowledge of their consumers' personality and preferences (Jones, 1999), credibility (Sharma \& Stafford, 2000), and communication ability (Ambady et al, 2006). Communication skills imply that sales assistants listen to the needs of the consumer and do not assume that they know what she wants (Schmidt, 2007), as the assistant's willingness to listen results in more positive responses from consumers (Clopton et al, 2001). Another characteristic of successful clothing sales assistants is that they be willing to do just about anything regarding assistance and service provision for the consumer (Beatty et al, 1996). These characteristics not only influence the sales assistant's image, but also determine whether consumers will return to the store for purchases (Clopton et al, 2001).
Lastly, the clothing sales assistant's appearance will affect the perception of the consumer (Figure 1). According to Regan and Llamas (2002), the manner in which people are judged and treated by others, is influenced by the clothes they wear. This is true because individuals' appearances can express a large amount of information about themselves (Solomon \& Rabolt, 2004:323). The consumers interpret the sales assistant's appearance as symbolic of his or her characteristics and representative of what the shop has to offer (De Klerk et al, 1998), and is important in establishing the relationship with the consumer (Jin \& Hong, 2004). Therefore, a sales assistant that appears to be professional may have a positive influence on the consumer's perception of him or her.

\section{The sales assistant's influence on consumers' emotions}

As shown in Figure 1, the clothing sales assistant, as well as the consumer's perception and expectations regarding the sales assistant influence the emotions of the consumer. Menon and Dubé (2000) state that the sales assistant's service will have an impact on the consumer's emotions and the consumer's response to these emotions. Thus, it determines how the consumer-sales assistant interaction will play out.

If the sales assistant has a positive emotional effect on the consumer, the consumer's' decision, through persuasion, to make a purchase is improved (Sharma \& Levy, 2003; Figure 1). Contrary to this effect, the negative effect that a sales assistant might have on a consumer will lead to a decrease in persuasion. This can be explained by the fact that, when a sales assistant has a negative effect on them, consumers assume that he or she does not have their interests in mind (Sharma, 2001), which will influence consumers' purchasing decision. Therefore, sales assistants play an essential role in the final purchase decision of the consumer (Solomon \& Rabolt, 2004:431; Figure 1); thus, the retailer needs to be familiar with the salesperson's characteristics that may have a positive effect on the consumer's emotions (Sharma \& Levy, 2003).

\section{The purchasing decision of the clothing consumer}

Figure 1 indicates that the emotions of consumers resulting from the clothing sales assistant's service provision will ultimately influence their purchasing decision. This implies that the retailer will gain or lose purchases or no influence on purchasing might occur. The susceptibility of the consumer to be influenced by the sales assistant may vary between individuals (Jin \& Hong, 2004). Yet, Cant et al (2006:2) indicate that the behaviour of the clothing sales assistant before, during, and after the purchase is linked to the consumer's behaviour in a clothing store. For this reason, it is important for the sales assistant to know how to behave towards consumers, to increase their purchases.

As in the case with all consumer decisions, the clothing consumer finds it important to gather information, 
evaluate alternatives, and make decisions at the point of purchase (Du Preez \& Visser, 2003). For example, female clothing consumers in Kazakhstan expect the input of the sales assistant when they are unsure or are shopping alone, which will influence their purchasing decision (Low \& Freeman, 2007). However, if the sales assistant is perceived to be untrustworthy or not actively involved, they will leave the store, resulting in the retailer losing purchases (Figure 1). The 'personal touch' of the clothing sales assistant will also affect purchasing behaviour (Low \& Freeman, 2007).

The decision-making process of individuals is preceded, determined, and followed by the mental (such as service evaluation) and physical activities (such as talking to salespeople) of which purchasing behaviour consists (Du Plessis \& Rousseau, 2003:9). The service quality of the sales assistant and the interaction with the sales assistant will therefore play an important role in consumer decision-making. For instance, consumers will end the interaction with annoying salespeople should they not need or want the item presented. Conversely, when a sales assistant attempts to sell the consumer something before they show interest or determine whether a need for the product exists, it will influence the consumer's purchasing decision negatively (Gage, 2006), resulting in the retailer losing purchases (Figure 1).

\section{METHODOLOGY}

\section{Research approach}

A qualitative, exploratory research approach was followed, as it allows the discovery of concepts not yet known, constructed during the investigation itself (Merkens, 2004:169). Furthermore, a qualitative research method was also suitable for this study, because qualitative research focuses on meanings of ideas and not quantities that are experimentally measured (Denzin \& Lincoln, 1998:8), which is suitable for interpreting consumers' perceptions. Qualitative research also attempts to gain a better understanding of the participants under investigation (Denzin \& Lincoln, 2000:3). The qualitative research approach illustrates the views of the participants being studied, without assuming that these views necessarily belong to others outside the study population (McCormack \& Hill, 1997:4). Therefore, the results obtained by this study cannot be generalised and are only representative of the specific retail outlet examined.

\section{Sampling}

A well-known clothing retail store in a shopping mall in Johannesburg was chosen as the study location. Johannesburg is South Africa's leading city and contributes to the economic revival (Rogerson, 2001), making it an ideal study environment. The in-store study environment was used to view the respondents in their actual shopping environment (Du Preez \& Visser, 2003). The busy nature of this shopping mall enabled the recruitment of more respondents.
No specific criteria for the selection of respondents for the study in terms of race and age were determined, but the study focused on female respondents as mentioned before. Respondents were approached on their way out of the store at the store's entrance for a oneto-one semi-structured interview, to retrieve their opinions about clothing sales assistants. This allowed the recruitment of female respondents with an interest in clothing, at a time when the respondents were better able to recollect their in-store experiences, as well as previous encounters with clothing sales assistants. The respondents did not necessarily have to purchase merchandise to be suitable respondents for the study, as the study was aimed at exploring different female consumers' perceptions and emotions regarding sales assistants and their consequent purchasing decision, regardless of whether they made purchases or not. The sampling technique used to recruit respondents was purposive, because it allows the identification of respondents who complied with the inclusion criteria and ensured the collection of relevant data (Strydom \& Delport, 2005:329).

\section{Data collection}

Twenty-five semi-structured interviews of approximately ten minutes each, using open-ended questions, were conducted over a period of three days in March 2006. According to Rubin and Rubin (1995:145), the use of semi-structured interviews allows the eliciting of specific information concerning consumer perceptions, while still allowing the exploration of unfamiliar information. Semi-structured interviews allowed the researcher and respondents to be more flexible (Greeff, 2005:296), by probing the respondent for more information. Using open-ended questions, the researcher can follow up on answers given by the respondents, to obtain a deeper insight of the respondents' points of view on the area under discussion (Greeff, 2005:296).

Respondents' contributions were audio recorded, to ensure an accurate recollection of their opinions, and field notes were also taken. The following questions were asked: What is your general ideas of clothing sales assistants in clothing stores? What effect does a clothing sales assistant have on your emotions? How does the clothing sales assistant's service provision influence your purchasing decision? Respondents were motivated to give their opinions on clothing retailers in South Africa in general, to prevent the result from being biased by possible previous encounters in the specific store used as the study location. A pilot study was conducted prior to the main study, to allow the researchers to familiarise themselves with the study field and test the suitability of the questions.

\section{Data analysis}

Data analysis was conducted through the process of qualitative content analysis, in order to classify or reduce the multitude of the respondents' words, representing the data, into fewer meaningful categories (Weber, 1990:12, 15). First, the audiotapes recorded during data collection were transcribed verbatim, to 
keep the data true to the original meaning of respondents. Where respondents responded in Afrikaans, their responses were carefully translated to English by the researchers, to maintain the original meaning of the respondents' statements. Another person also proficient in both languages verified the translations, to ensure the objectivity and correctness thereof.

The transcription of data, as well as the typing of the field notes, allowed the researchers to become immersed in the data and view the data as a whole (De Vos, 2005:337). Forty-seven pages of data were transcribed. Both the transcriptions and the field notes were used for coding the data and allowed the researchers to refer back constantly during analysis (Hayes, 2000:174).

The second step of content analysis was the coding of data, using the process of open coding. This method of data-analysis allowed the researchers to analytically "break down" (Böhm, 2004:271) order, structure and interpret the data (Marshall \& Rossman, 1999:150). Transcripts for each question posed to respondents and referring to a specific secondary objective of the study were coded separately. The researchers categorised phenomena through a close examination of the data for similarities and differences, and grouped concepts around each phenomenon (De Vos, 2005:341). For example, respondents' opinions portraying similar perceptions regarding the clothing sales assistant were categorised manually into concepts describing the first research objective, to determine consumers' perceptions of the clothing sales assistant. All questions from the semi-structured interviews were categorised according to concepts in the same manner. The number of concepts referring to each research objective was reduced further, by classing the concepts into categories (De Vos, $2005: 341)$. The latter were again categorised into themes relevant to the research objectives.

\section{Trustworthiness}

A high level of trustworthiness was sought during each part of the study. Trustworthiness was guaranteed in this study by using Guba's model for trustworthiness (Lincoln \& Guba, 1985:372) in combination with Krefting's (1991) criteria. Credibility was achieved by allowing the researchers to gain field experience (conducting a pilot study, continuing with semistructured interviews until data saturation was reached, and allowing sufficient time for semistructured interviews), reflexibility (comparing field notes with transcribed data), triangulation (using field notes and transcribed data for data analysis and literature control on clothing sales assistants), and the semi -structured interview technique (training of researchers in the methodology used and initial supervision of researchers by more experienced peers). The strategy of transferability was applied, by selecting respondents purposively and using verbatim quotations to support data. Dependability was obtained by means of a dense description of the methodology, a dependability audit on the themes, categories and concepts by experienced researchers, triangulation (using themes, categories, and concepts formulated individually by researchers), and peer examination by experienced researchers through regular discussions. Lastly, conformability was achieved through a conformability audit (keeping all field notes and transcriptions).

\section{Ethical considerations}

The researchers were stationed at the entrance of the store and the respondents were only approached at the end of their shopping excursion, to disturb the respondents as little as possible. The researchers made sure that the respondents felt comfortable about participating in the study by explaining the objectives of the study to them. The respondents were asked permission for their participation and being tape recorded during the semi-structured interview, and were assured of their anonymity. Each respondent had to sign an informed consent form before participating in the study. The respondents also had the right to withdraw from the study at any time during the semistructured interview. Ethical approval for this project was provided by the North-West University (reference code 06K09).

\section{RESULTS AND DISCUSSION}

The following results were obtained from the semistructured interviews with the respondents. The statements given in Tables 1, 2, 3, and 4 represent examples as they were recorded during semi-structured interviews, but do not include all statements due to space limitations. The data are presented in the order of questions asked of respondents, in order to answer the objectives of the study

Respondents' expectations regarding the clothing sales assistant's assistance and service provision

When respondents were asked about their general ideas regarding the clothing sales assistant, in order to determine their perceptions, some respondents expressed their expectations regarding sales assistants. Table 1 provides a summary of the themes, categories, and concepts identified in the data, as well as supporting examples of participants' statements from the transcripts. Participants' expectations were categorised into two themes: the attributes the sales assistant should avoid and those for which they should strive. The first theme was addressed through concepts of the sales assistant following the respondent around and intrusive sales assistants. Beatty et al (1996) explain that consumers want convenient, hassle-free shopping. It is evident that clothing sales assistants should avoid intrusive behaviour, as this might influence the sales in the store negatively. The clothing sales assistant should give the consumer enough space to allow them to make their own decisions and strive for attributes valued by consumers.

Respondents verbalised the attributes that the sales assistants should strive for in terms of three categories, namely their characteristics, etiquette, and skills (Table 1). Concepts, such as availability, helpfulness, friendliness, enthusiasm, and being knowledgeable 
TABLE 1: DATA REFLECTING RESPONDENTS' EXPECTATIONS REGARDING THE CLOTHING SALES ASSISTANT'S ASSISTANCE AND SERVICE PROVISION

\begin{tabular}{|c|c|c|c|}
\hline Theme & Category & Concept & Examples of respondents' statements \\
\hline \multirow{2}{*}{$\begin{array}{l}\text { Attributes sales } \\
\text { assistant should } \\
\text { avoid }\end{array}$} & & $\begin{array}{l}\text { Following consumer } \\
\text { around }\end{array}$ & $\begin{array}{l}\text { "Not following you around as if you are } \\
\text { going to steal." }\end{array}$ \\
\hline & & $\begin{array}{l}\text { Intrusive sales } \\
\text { assistants }\end{array}$ & "they must not overpower you ..." \\
\hline \multirow[t]{11}{*}{$\begin{array}{l}\text { Attributes sales } \\
\text { assistant should } \\
\text { strive for }\end{array}$} & \multirow[t]{5}{*}{$\begin{array}{l}\text { Sales assistants' } \\
\text { characteristics }\end{array}$} & Availability & $\begin{array}{l}\text { "If there is something that I need then I } \\
\text { know that they are there and I can go to } \\
\text { them." }\end{array}$ \\
\hline & & Helpfulness & $\begin{array}{l}\text { "... show me where the items are that } \\
\text { I'm looking for." }\end{array}$ \\
\hline & & Friendliness & "... should be friendly and welcoming." \\
\hline & & Enthusiasm & "They must be enthusiastic." \\
\hline & & Knowledgeability & "They must know their products..." \\
\hline & \multirow{3}{*}{$\begin{array}{l}\text { Sales assistants' } \\
\text { etiquette }\end{array}$} & Professionalism & "... must be professional" \\
\hline & & Patience & be patient." \\
\hline & & Honesty & "Honesty is the word." \\
\hline & \multirow[t]{3}{*}{$\begin{array}{l}\text { Sales assistants' } \\
\text { skills }\end{array}$} & $\begin{array}{l}\text { Communication } \\
\text { skills }\end{array}$ & "Have good communication skills." \\
\hline & & Versatility in skills & "They must be an all rounder ..." \\
\hline & & Specialised skills & $\begin{array}{l}\text { "They need to have different skills, } \\
\text { because they're dealing with different } \\
\text { things." }\end{array}$ \\
\hline
\end{tabular}

TABLE 2: $\quad$ DATA REFLECTING RESPONDENTS' PERCEPTIONS OF THE CLOTHING SALES ASSISTANT IN A CLOTHING STORE

\begin{tabular}{|c|c|c|c|}
\hline Theme & Category & Concept & $\begin{array}{l}\text { Examples of respondents' } \\
\text { statements }\end{array}$ \\
\hline \multirow{5}{*}{$\begin{array}{l}\text { Positive } \\
\text { perceptions of } \\
\text { sales assistant }\end{array}$} & \multirow[t]{3}{*}{$\begin{array}{l}\text { Positive characteristics of } \\
\text { sales assistant }\end{array}$} & Helpfulness & $\begin{array}{l}\text { "Some salespeople are very } \\
\text { helpful." }\end{array}$ \\
\hline & & Friendliness & $\begin{array}{l}\text { "They are friendly and pleasant } \\
\text { in general." }\end{array}$ \\
\hline & & Competence & $\begin{array}{l}\text { "... in some store the people } \\
\text { are excellent." }\end{array}$ \\
\hline & \multirow[t]{2}{*}{$\begin{array}{l}\text { Respondents' positive } \\
\text { mindset towards sales } \\
\text { assistant }\end{array}$} & $\begin{array}{l}\text { Participants' satisfaction } \\
\text { with sales assistants' } \\
\text { service }\end{array}$ & $\begin{array}{l}\text { "In general I'm happy with their } \\
\text { service." }\end{array}$ \\
\hline & & $\begin{array}{l}\text { Participants' tolerance } \\
\text { toward sales assistants }\end{array}$ & $\begin{array}{l}\text { "I'm quite tolerant towards } \\
\text { them." }\end{array}$ \\
\hline \multirow{6}{*}{$\begin{array}{l}\text { Negative } \\
\text { perceptions of } \\
\text { sales assistant }\end{array}$} & \multirow[t]{5}{*}{$\begin{array}{l}\text { Negative characteristics } \\
\text { of sales assistant }\end{array}$} & $\begin{array}{l}\text { Following the participant } \\
\text { around }\end{array}$ & $\begin{array}{l}\text { "When you don't need them } \\
\text { they're always there." }\end{array}$ \\
\hline & & Intrusive sales assistant & $\begin{array}{l}\text { "They force their taste on you } \\
\text {..." }\end{array}$ \\
\hline & & Unhelpfulness & $\begin{array}{l}\text { "You help yourself ... they're } \\
\text { not willing to help ..." }\end{array}$ \\
\hline & & Unfriendliness & $\begin{array}{l}\text { "They are very unfriendly. It } \\
\text { looks like it is very hard for } \\
\text { them to work here." }\end{array}$ \\
\hline & & Incompetence & $\begin{array}{l}\text { "All the personnel are not well } \\
\text { infomed about things." }\end{array}$ \\
\hline & $\begin{array}{l}\text { Respondents' negative } \\
\text { mindset towards sales } \\
\text { assistant }\end{array}$ & $\begin{array}{l}\text { Consumers' aversion } \\
\text { with sales assistants' } \\
\text { service }\end{array}$ & $\begin{array}{l}\text { "I think their services are very } \\
\text { poor ..." }\end{array}$ \\
\hline
\end{tabular}


are characteristics for which the sales assistant should strive. The category of etiquette included concepts, such as professionalism, patience, and honesty. Skills that sales assistants should develop included concepts of communications skills, versatility in skills, and specialised skills.

Jin and Hong (2004) also indicate that the attributes of clothing sales assistants are important, as some characteristics may influence the purchasing decision of the consumer more than others. Previous research confirmed that availability (Sharma, 2001) and friendliness (De Klerk et al, 1998) are important characteristics of clothing sales assistants. The availability of the clothing sales assistant is essential to the consumer, because they must be nearby should the consumer require assistance or fashion advice. Darian et al's (2001) study in electronic retail stores also indicates the product knowledge and friendliness of sales assistants as important in determining purchase intentions. A knowledgeable sales assistant is also perceived as more friendly, honest, and helpful (Clopton et al, 2001). In addition to knowledge, Beatty et al (1996) state that the sales assistant should acquire skills, such as patience, self-respect, and respect for other individuals, with emphasis on being honest with consumers, as these qualities are important to the consumer, which were confirmed by the present study.

The attributes that resulted from the respondent's semi-structured interviews can be used as a guideline by which clothing sales assistants can direct their behaviour towards the consumer, and might be implemented into their training, as these attributes could influence consumers' purchasing behaviour.

\section{Respondents' perceptions of the clothing sales assistant in a clothing store}

Amongst various other factors, the expectations that were discussed have an impact on the consumer's perception of the clothing sales assistant (Stanforth \& Lennon, 1997). Respondents' discussions about the perceptions of the clothing sales assistant are divided into two themes, namely positive and negative perceptions (Table 2).

The categories that emerged in terms of respondents' positive perceptions regarding the clothing sales assistant, were positive characteristics of the sales assistant and respondents' positive mindset towards the clothing sales assistant. The positive characteristics concepts included the same characteristics that respondents expect the sales assistant to strive for, such as helpfulness, friendliness, and competence. Respondents' positive mindset towards the clothing sales assistant was verbalised through the concepts respondents' satisfaction with sales assistants' service and respondents' tolerance towards sales assistants.

Respondents' negative perceptions of the clothing sales assistant resulted in the categories: negative characteristics of the clothing sales assistant and the negative mindset of the respondent toward the sales assistant. As indicated for positive perceptions, nega- tive characteristics included concepts similar to those the respondent expects the sales person to avoid, such as following the respondent around and being intrusive, as well as other concepts indicating the opposite conduct of the positive characteristics mentioned. The category of the respondent's negative mindset towards the clothing sales assistants singled out a concept of respondents' aversion with sales assistants' service.

A sales assistant's characteristics and their behaviour toward consumers will evoke a positive or negative feeling in the consumer (Lee \& Dubinsky, 2003). Respondents in Arnold et af's (2005) study in different retail environments felt that the salespeople ignored them based on their clothing, which was confirmed by some respondents in the present study ("... if I can come here wearing something funny, believe you me they won't even look at me"). This negative behaviour of the clothing sales assistant can be explained by the sales assistant being prone to behave more negatively towards consumers should they disapprove of the appearance or communication style of the consumer (Clopton et al, 2001). Respondents in Menon and Dubé's study (2000) were angered by the clothing sales assistant ignoring them or being unhelpful, rude, or pressuring. The retailer should endeavour to eliminate the negative characteristics of the clothing sales assistant, replacing them with the desired positive characteristics, by providing the clothing sales assistant with the necessary training.

\section{Respondents' emotions that are evoked by the clothing sales assistant during shopping}

The behaviour of the sales assistant has an effect not only on respondents' perceptions, but on their emotions as well (Menon \& Dubé, 2000). Results from the present study are provided in Table 3. Respondents' emotions are expressed as the theme of feelings caused by the sales assistant's conduct. The first category is pressured feelings addressed through concepts of pressure to purchase and insufficient time to make a decision. The second category of feelings caused by the sales assistant is irritation due to the sales assistant's annoying behaviour, such as following the consumer around.

The third category is uncomfortable feelings, such as feeling uncomfortable about being followed and the forceful sales assistant as concepts. One respondent expressed her discomfort by saying: "I don't feel comfortable ... I don't know if they think I'm going to steal something ....". Lastly, sales assistants also evoked feelings of sadness in respondents, the third affective category. This was especially the case when the consumer was treated with disrespect. Darian et al (2001) found that respondents viewed sales assistants who talk down to them more negatively and that respect is one aspect that would motivate consumers to buy from a retailer.

Previous work indicated that the sales assistant has both positive (Menon \& Dubé, 2000) and negative (Sharma \& Levy, 2003) effects on consumers' emotions. However, respondents' in the present study focused on the negative emotions, something that 
TABLE 3: DATA REFLECTING THE RESPONDENTS' EMOTIONS EVOKED BY THE CLOTHING SALES ASSISTANT DURING SHOPPING

\begin{tabular}{|c|c|c|c|}
\hline Theme & Category & Concept & $\begin{array}{l}\text { Examples of respondents' } \\
\text { statements }\end{array}$ \\
\hline \multirow{7}{*}{$\begin{array}{l}\text { Feeling caused by } \\
\text { the sales assistant's } \\
\text { conduct }\end{array}$} & \multirow[t]{2}{*}{$\begin{array}{l}\text { Pressured } \\
\text { feelings }\end{array}$} & Pressure to purchase & $\begin{array}{l}\text { "Sometimes I feel pressured, like I have } \\
\text { to take this." }\end{array}$ \\
\hline & & $\begin{array}{l}\text { Insufficient time to make } \\
\text { decision }\end{array}$ & $\begin{array}{l}\text { "You don't get time to make your own } \\
\text { decision." }\end{array}$ \\
\hline & \multirow[t]{2}{*}{$\begin{array}{l}\text { Feelings of } \\
\text { irritation }\end{array}$} & $\begin{array}{l}\text { Irritation due to } \\
\text { annoying sales } \\
\text { assistant }\end{array}$ & $\begin{array}{l}\text { "... When they are like over you, you } \\
\text { feel irritated and then you just want to } \\
\text { leave." }\end{array}$ \\
\hline & & $\begin{array}{l}\text { Irritation about being } \\
\text { followed by sales } \\
\text { assistant }\end{array}$ & $\begin{array}{l}\text { "It's sometimes an irritation if they walk } \\
\text { behind you." }\end{array}$ \\
\hline & \multirow[t]{2}{*}{$\begin{array}{l}\text { Uncomfortable } \\
\text { feelings }\end{array}$} & $\begin{array}{l}\text { Uncomfortable about } \\
\text { being followed }\end{array}$ & $\begin{array}{l}\text { "but when someone is following me it } \\
\text { makes me feel uncomfortable" }\end{array}$ \\
\hline & & $\begin{array}{l}\text { Uncomfortable about } \\
\text { forceful sales assistant }\end{array}$ & $\begin{array}{l}\text { "... if they force their taste on you .... } \\
\text { they make me feel uncomfortable ..." }\end{array}$ \\
\hline & $\begin{array}{l}\text { Feelings of } \\
\text { sadness }\end{array}$ & $\begin{array}{l}\text { Sadness about } \\
\text { disrespectful sales } \\
\text { assistant }\end{array}$ & $\begin{array}{l}\text { "Some of them actually walk away from } \\
\text { me... I actually sometimes want to cry." } \\
\text { "... it is like they undemine people ... I } \\
\text { feel like l'm nothing ... you feel like } \\
\text { maybe l'm not worth it ..." }\end{array}$ \\
\hline
\end{tabular}

TABLE 4:

DATA REFLECTING THE INFLUENCE OF THE CLOTHING SALES ASSISTANT ON THE RESPONDENT'S PURCHASING DECISION

\begin{tabular}{|c|c|c|}
\hline Theme & Concept & Examples of respondents' statements \\
\hline \multirow{5}{*}{$\begin{array}{l}\text { The retailer gaining } \\
\text { purchases }\end{array}$} & Helpfulness & "I mean if they help you it motivates you to buy more." \\
\hline & \multirow[t]{2}{*}{ Friendliness } & $\begin{array}{l}\text { "I expect them to be friendly ... then I will buy } \\
\text { something more..." }\end{array}$ \\
\hline & & $\begin{array}{l}\text { "You end up sometimes buying even when you don't } \\
\text { want to buy, because the guy is very nice." }\end{array}$ \\
\hline & Feeling at home & "You buy more when you feel at home in a shop." \\
\hline & $\begin{array}{l}\text { Encouraging sales } \\
\text { assistants }\end{array}$ & "... some encourage you to buy more." \\
\hline \multirow[t]{4}{*}{$\begin{array}{l}\text { The retailer losing } \\
\text { purchases }\end{array}$} & Purchasing elsewhere & $\begin{array}{l}\text { "If I can get the product at another place I would } \\
\text { rather buy it here..." }\end{array}$ \\
\hline & \multirow[t]{2}{*}{ Not purchasing } & "I'll leave the products and go." \\
\hline & & $\begin{array}{l}\text { "They make me feel urwelcome and then I'm not in } \\
\text { the mood to buy." }\end{array}$ \\
\hline & Delayed purchasing & $\begin{array}{l}\text { "Usually I just go away and then come back when } \\
\text { there is nobody there." }\end{array}$ \\
\hline \multirow[t]{3}{*}{$\begin{array}{l}\text { No influence on } \\
\text { purchasing decision }\end{array}$} & $\begin{array}{l}\text { Respondents know what } \\
\text { they want }\end{array}$ & "I know what I want and I just go in and get it." \\
\hline & $\begin{array}{l}\text { Respondent tolerating the } \\
\text { inconvenience }\end{array}$ & $\begin{array}{l}\text { "It depends, I buy what I like. I tolerate the } \\
\text { inconvenience..." }\end{array}$ \\
\hline & $\begin{array}{l}\text { Getting alternative } \\
\text { assistance }\end{array}$ & "... or I will ask somebody else to help me." \\
\hline
\end{tabular}

should be of concern to the South African clothing retail industry. Results in a study by Jones (1999) indicate that the respondents had a more enjoyable shopping experience without the presence of an overbearing sales assistant, while sales assistants that are too 'pushy' can create an unpleasant shopping experience for consumers (Arnold et al, 2005). The emo- tions that consumers experience during shopping have a definite influence on the consumer's purchasing decision (Sharma \& Levy, 2003).

The influence of the clothing sales assistant on the respondent's purchasing decision 
From the above discussion, it is clear that the emotions of a consumer will influence their purchasing decision. Previous research indicates that the interaction between the clothing sales assistant and the consumer will determine whether repeat purchasing will take place (De Klerk et al, 1998), affecting the sales (Reynolds \& Arnold, 2000) of a clothing retailer. In the present study, respondents' opinions regarding the influence of the clothing sales assistant on their purchasing decision are categorised into three themes, namely the retailer gaining purchases, the retailer losing purchases, and no influence on purchasing decision (Table 4). The retailer gaining purchases was addressed by mentioning concepts that would inspire the respondent to purchase, namely helpfulness and friendliness of the clothing sales assistant, as well as feeling at home and encouraging sales assistants.

It is evident that clothing consumers will be more likely to purchase merchandise from a sales assistant with positive characteristics than one with negative characteristics, which leads to increased sales for the clothing retailer. Beatty et al (1996) confirm that the respondents felt pressured into purchasing merchandise, even should they not wish to purchase clothes, when they had a 'close' relationship with the sales assistant. Therefore, this indicates that the retailer can encourage purchases by guiding their clothing sales assistants in offering the consumer the best assistance, in order to establish a trusting relationship with the consumer.

The theme of the retailer losing purchases was divided into three categories, namely, purchasing elsewhere, not purchasing, and delayed purchasing (Table 4). In the latter case, some respondents indicated delayed purchasing in that they avoid the sales assistant about whom they have negative feelings and return for purchases only when the particular sales assistant is not present. Thus, it is important for the clothing retailer to understand the essence of sales assistants' behaviour and the effects this has on customers' perceptions of their store.

The theme of no influence on purchasing decision was addressed through the concepts: respondent knows what he or she wants, respondent tolerating the inconvenience caused by the sales assistant, and respondent gaining alternative assistance. Despite the significant influence that the clothing sales assistant can have on consumers' purchasing decisions, there is a small number of consumers that will not allow the sales assistant to influence their purchasing behaviour. It is in clothing retailers' best interests not to rely on this type of consumer behaviour, as not all consumers will respond in this manner.

\section{CONCLUSION}

When the clothing sales assistant and the female consumer interact in the clothing shop, the sales assistant's attributes (approach, behaviour, characteristics, and appearance) will influence the consumer's perceptions of the store and thereby influence purchasing decisions. Helpful, competent, and friendly sales assistants will create a positive frame of mind amongst consumers, which will lead to consumer satisfaction with the sales assistant's service. However, the opposite was also found in the study.

Furthermore, it was found that the clothing consumer's perceptions would be influenced by the consumer's expectations. Each consumer has different expectations regarding the clothing sales assistant, and should these expectations not be met while interacting with the assistant, his or her perception of the assistant (and by implication, the store) will be negatively influenced. Negative encounters with the sales assistant can also evoke negative emotions in the consumer, which can have a negative effect on the retailer in terms of sales. Positive effects are that the clothing consumer will purchase merchandise, and in some cases, even purchase additional merchandise that they did not intend purchasing initially. The retailer is fortunate that some consumers do not allow their emotions to affect their purchasing decision and still purchase at the specific store, regardless of the sales assistant's behaviour, appearance, characteristics, or initial approach.

\section{MANAGERIAL IMPLICATIONS OF RESEARCH FINDINGS}

This study aimed at exploring a relatively unknown field of research in the South African context. Owing to its qualitative and exploratory nature and small sample size, the results cannot be generalised to all South African clothing retail outlets and the results are thus applicable only to the specific retail outlet used as the study location. In order for retailers to make use of this research, similar studies should be done in their own stores. The results of this study could however be used to perform a national quantitative survey, representing the female consumer population of South Africa. The results of such a study would allow retailers to apply the data to their staff training programmes. This will enable them to handle customer complaints more effectively, leading to more satisfied customers, who are likely to return for more purchases in future.

The results of the present study may also increase the retailer's awareness of the negative effects that the sales assistant can have on the consumer and their purchasing decision. This awareness will allow the retailer to understand the factors that influence the interaction between the two parties in-store better. Should the retailer disregard this information, it is possible that they can lose valuable consumer support and sales. Furthermore, because the clothing sales assistant plays such a vital role in the clothing store, the clothing consumer's perception of the sales assistant will also influence the image of the store.

With regard to clothing sales assistants, this study might focus their attention on the significant impact that their approach, behaviour, characteristics, and appearance can have on the consumer's perception, emotions, and purchasing decision. This will allow 
them to be more considerate in their approach toward the consumer, which may lead to the consumer benefiting from a more satisfying clothing shopping experience.

\section{RECOMMENDATION FOR FUTURE RESEARCH}

Potential for future research in this field of study was identified in terms of the effect the consumer has on the clothing sales assistant's behaviour towards the consumer. Furthermore, as mentioned above, this type of research should also be performed quantitatively in various clothing stores located in South Africa. The results of such research could be more detailed, with a broader understanding of consumers' opinions about the topic under discussion, which will allow results to be generalised to a wider section of the South African population.

\section{REFERENCES}

AMBADY, N, KRABBENHOFT, MA \& HOGAN, D. 2006. The 30-sec sale: using thin-slice judgments to evaluate sales effectiveness. Journal of Consumer Psychology 16(1):4-13.

ARNOLD, MJ, REYNOLDS, KE, PONDER, N \& LUEG, JE. 2005. Customer delight in a retail context: investigating delightful and terrible shopping experiences. Journal of Business Research 58(8):11321145.

BEATTY, SE, MAYER, M, COLEMAN, JE, REYNOLDS, KE \& LEE, J. 1996. Customer-sales associate retail relationships. Journal of Retailing 72(3):223247.

BLEM, N. 2007. Achieving excellence in selling. Cape Town. Oxford University Press.

BÖHM, A. 2004. Theoretical coding: text analysis in grounded theory. In Flick, U, Von Kardoff, E \& Steinke, I. 2004. A companion to qualitative research. London. Sage.

BRISTOW, DN, GULATI, R, AMYX, D \& SLACK, J. 2006. An empirical look at professional selling from a student perspective. Journal of Education for Business 81(5):242-249.

CANT, M, BRINK, A \& BRIJBALL, S (eds). 2006. Consumer behaviour. 2nd ed. Cape Town. Juta.

CLOPTON, SW, STODDARD, JE \& CLAY, JW. 2001.

Sales assistant characteristics affecting consumer complaint responses. Journal of Consumer Behaviour 1(2):124-139.

DARIAN, JC, TUCCI, LA \& WIMAN, AR. 2001. Perceived salesperson service attributes and retail patronage intentions. International Journal of Retail and Distribution Management 29(5):205-213.

DE KLERK, HM, VELLEMAN, AK \& MALHERBE, E. 1998. 'n Kwalitatiewe ondersoek na die invloed van aspekte van die klerewinkel en die verkoopsdame se voorkoms op die damesklereverbruiker se besluitnemingsproses. Journal of Family Ecology and Consumer Sciences 26(1):15-26.

DE VOS, AS. 2005. Qualitative data analysis and interpretation. In De Vos, AS. 2005. Research at grass roots: for the social sciences and human service pro- fessions. 3rd ed. Pretoria. Van Schaik.

DENZIN, NK \& LINCOLN, YS. 1998. Collecting and interpreting qualitative materials. London. Sage.

DENZIN, NK \& LINCOLN, YS. 2000. Handbook of qualitative research. 2nd ed. London. Sage.

DU PLESSIS, PJ \& ROUSSEAU, GG. 2003. Buyer behaviour. A multi-cultural approach. 3rd ed. Cape Town. Oxford University Press.

DU PREEZ, R \& VISSER, EM. 2003. Apparel shopping behaviour - part 2: conceptual theoretical model, market segments, profiles and implications. South African Journal of Industrial Psychology 29(3):15-20.

DU PREEZ, R. 2003. Apparel shopping behaviour part 1: towards the development of a conceptual theoretical model. South African Journal of Industrial Psychology 29(3):11-14.

GAGE, K. 2006. You haven't earned the right sell to me! Enterprise/Salt Lake City 35(32):9.

GREEFF, M. 2005. Information collection: interviewing. In De Vos, AS. 2005. Research at grass roots: for the social sciences and human service professions. 3rd ed. Pretoria. Van Schaik.

HAYES, N. 2000. Doing psychological research: gathering and analyzing data. Buckingham. Open University Press.

HEEBNER, J. 2006. It's all about the bride. Jewellers Circular Keystone (January):66-70. Available on line. URL: http://www.jckonline.com/article/ CA6296737.html. Accessed 7 October 2008.

$\mathrm{HU}, \mathrm{H}$ \& JASPER, C.R. 2006. Social cues in the store environment and their impact on store image. International Journal of Retail and Distribution Management 34(1):25-48.

JIN, B \& HONG, B. 2004. Consumer susceptibility to salesperson influence in Korean department stores. Journal of International Consumer Marketing 17(1):3352.

JONES, MA. 1999. Entertaining shopping experiences: an exploratory investigation. Journal of Retailing and Consumer Services 6(3):129-139.

KAWABATA, H \& RABOLT, NJ. 1999. Comparison of clothing purchase behaviour between US and Japanese female university students. Journal of Consumer Studies and Home Economics 23(4):213-223.

KREFTING, L. 1991. Rigor in qualitative research: the assessment of trustworthiness. The American Journal of Occupational Therapy 45(3):214-222.

LASCHINGER, K. 2004. Not dying but adapting. Finance Week 5 (May):18-20.

LEE, S \& DUBINSKY, AJ. 2003. The influence of sales assistant characteristics and customer emotion on retail dyadic relationships. The International $R e$ view of Retail, Distribution and Consumer Research 13(1):21-36.

LINCOLN, AS \& GUBA, EG. 1985. Naturalistic inquiry. London. Sage.

LINDQUIST, JD \& KAUFMAN-SCARBOROUGH, CF. 2004. Polychronic tendency analysis: a new approach to understanding woman's shopping behaviour. Journal of Consumer Marketing 21(5):332-342.

LOW, P \& FREEMAN, I. 2007. Fashion marketing to women in Kazakhstan. Journal of Fashion Marketing and Management 11(1):41-55.

MARSHALL, G \& ROSSMAN, GB. 1999. Designing qualitative research. 3rd ed. London. Sage. 
McCORMACK, B \& HILL, E. 1997. Conducting a survey. 1st ed. London. Thomson.

MENON, K \& DUBÉ, L. 2000. Ensuring greater satisfaction by engineering sales assistant response to customer emotions. Journal of Retailing 76(3):285307.

MERKENS, H. 2004. Selection procedures, sampling, case construction. In Flick, U, Von Kardorff, E, \& Steinke, I. 2004. A companion to qualitative research. London. Sage.

MICHON, R, YU, H, SMITH, D \& CHEBAT, J. 2008. The influence of mall environment on female fashion shoppers' value and behaviour. Journal of Fashion Marketing and Management 12(4):456-468.

PARMENTIER, S. 2005. Competing to win: exceeding in-store experience expectations. Yard and Garden 29 (2):7-8.

REGAN, PC \& LLAMAS, V. 2002. Customer service as a function of shopper's attire. Psychological Reports 90(1):203-204.

REYNOLDS, KE \& ARNOLD, MJ. 2000. Customer loyalty to the sales assistant and the store: examining relationship customers in an upscale retail context. Journal of Personal Selling and Sales Management (20)2:89-98.

REYNOLDS, KE \& BEATTY, SE. 1999. Customer benefits and company consequences of customersales assistant relationships in retail. Journal of $R e-$ tailing 75(1):11-32.

ROGERSON, CM. 2001. Inner-city economic revitalisation through cluster support: the Johannesburg clothing industry. Urban Forum 12(1):49-71.

RUBIN, HJ \& RUBIN, IS. 1995. Qualitative interviewing: the art of hearing data. Thousand Oaks, California. Sage.
SCHMIDT, G. 2007. Women and clothing: too many assumptions will only help you lose the sale. Dealernews (January):36.

SHARMA, A \& LEVY, M. 2003. Salespeople's affect toward customer. Why should it be important for retailers? Journal of Business Research 56(7):523-528.

SHARMA, A \& STAFFORD, TF. 2000. The effect of retail atmospherics on consumers' perceptions of salespeople and customer persuasion: an empirical investigation. Journal of Business Research 49(2):183 $-191$.

SHARMA, A. 2001. Consumer decision-making, salespeople's adaptive selling and retail performance. Journal of Business Research 54(2):125-129.

SOLOMON, MR \& RABOLT, NJ. 2004. Consumer behavior in fashion. Upper Saddle River, New Jersey. Prentice Hall.

SOLOMON, MR. 2004. Consumer behavior: buying, having and being. 6th ed. Upper Saddle River, New Jersey. Pearson.

STANFORTH, NF \& LENNON, SJ. 1997. The effects of customer expectations and store policies on retail sales assistant service, satisfaction, and patronage. Clothing and Textiles Research Journal 15(2):115124.

STRYDOM, H \& DELPORT, CSL. 2005. Sampling and pilot study in qualitative research. In De Vos, AS. 2005. Research at grass roots: for the social sciences and human service professions. 3rd ed. Pretoria. Van Schaik.

TERBLANCHE, NS \& BOSHOFF, C. 2003. The controllable elements of the total retail experience: a study of clothing shoppers. South African Journal of Economics and Marketing Sciences 6(1):143:155.

WEBER, RP. 1990. Basic content analysis. 2nd ed. Newbury Park, California. Sage. 